\title{
FAKTOR-FAKTOR YANG BERKONTRIBUSI TERJADINYA PERITONITIS PADA PASIEN CONTINUOUS AMBULATORY PERITONEAL DIALYSIS (CAPD) DI RUMAH SAKIT UMUM DR SAIFUL ANWAR MALANG
}

\author{
Contributing Factors For Peritonitis Incidence On Continuous Ambulatory Peritoneal \\ Dialysis (CAPD) Patients In Dr Saiful Anwar Malang Hospital
}

\author{
Supono \\ Program Studi Keperawatan Lawang Poltekkes Kemenkes Malang \\ J1. A. Yani No 1 Lawang 65218 \\ e-mail: onop_kmb@yahoo.com
}

\begin{abstract}
ABSTRAK
Continuous ambulatory peritoneal dialysis (CAPD) adalah dialisis yang dilakukan melalui rongga peritonium (rongga perut) dengan selaput atau membran perutonium berfungsi sebagai filter. Tindakan CAPD dilakukan dengan insisi kecil pada dinding abdomen untuk pemasangan kateter, risiko komplikasi yang sering terjadi adalah infeksi pada peritonium (peritonitis). Tujuan penelitian untuk mengetahui hubungan faktor-faktor yang berkontribusi terjadinya peritonitis pada pasien CAPD di Rumah Sakit Umum Dr Saiful Anwar Malang Jawa Timur. Jenis penelitian deskkriptif korelasi dengan rancangan cross sectional study. Jumlah sampel penelitian 22 pasien peritonitis CAPD dan 13 perawat dialisis, dengan tehnik pengambilan sample menggunakan total sampling. Hasil penelitian menunjukan ada hubungan yang signifikan antara status nutrisi $(\mathrm{p}=0,032)$, kemampuan perawatan $(\mathrm{p}=0,024)$ dengan kejadian peritonitis pada pasien CAPD. Tidak ada hubungan yang signifikan antara umur $(\mathrm{p}=0,702)$, jenis kelamin $(\mathrm{p}=0,669)$, tingkat pendidikan ( $\mathrm{p}$ $=0,771)$, penghasilan $(\mathrm{p}=1,000)$, personal hygine $(\mathrm{p}=0,387)$, support system $(\mathrm{p}=1,000)$, fasilitas perawatan $(\mathrm{p}=0,088)$, standar struktur $(\mathrm{p}=0,203)$, standar proses $(\mathrm{p}=0,559)$ dengan kejadian peritonitis pada pasien CAPD. Rekomendasi untuk perawat meningkatkan kunjungan rumah untuk memberikan pendidikan kesehatan tentang perawatan dialisis dan pengeloaan nutrisi seimbang. Saran untuk pasien diharapkan mengikuti prosedur standar perawatan yang telah diajarkan.
\end{abstract}

Kata kunci: peritonitis, CAPD, perawat, pasien CAPD

\begin{abstract}
Continuous ambulatory peritoneal dialysis (CAPD) is a dialysis conducted through peritonium with perutonium membrane functions as a filter. CAPD procedure is conducted by making small incision on abdomen wall to insert catheter. Complication risk which often happens is the infection on peritoneum (peritonitis). The purpose of this research was to find out the relationship between contributing factors for peritonitis incidence on CAPD patients in Dr Saiful Anwar hospital in Malang, East Java. The type of this research was correlation descriptive cross sectional study design. The number of the sample were 22 peritonitis CAPD patients and 13 dialysis patients, using total sampling technique. The result showed that there was significant relationship between nutrition status $(p=0,032)$, treatment capability $(p=$ $0,024)$ with peritonitis incidence on CAPD patients. There was no significant relationship between age $(p=0,702)$, sex or gender $(p=0,669)$, level of education $(p=0,771)$, income $(p=1,000)$, personal hygiene $(p=0,387)$, support system $(p=1,000)$, treatment facilities $(p=0,088)$, structure standard $(p=$ $0,203)$, process standard $(p=0,559)$ with peritonitis incidence on CAPD patients. It is recommended to nurses to increase home visit to give health education about dialysis treatment and balanced nutrition management. It is also suggested to the patients to follow procedure for standard treatment which had been taught to them.
\end{abstract}

Keywords: peritonitis, CAPD, nurse, CAPD patient 
yang dilakukan melalui rongga peritoneum (rongga perut) yang berfungsi sebagai filter adalah selaput atau membran peritoneum (selaput rongga perut), sehingga CAPD sering disebut "cuci darah" melalui perut (Anonim, 2007). Thomas (2003, dalam Yetti, 2007) mengemukakan bahwa CAPD sebagai salah satu alternatif terapi pengganti pada penyakit ginjal tahap akhir (PGTA) telah diinstruksikan sejak tahun 1974 oleh Popovich dan Moncrief.

Terapi CAPD semakin meluas termasuk di Indonesia. Rumah Sakit PGI Cikini Jakarta sejak awal tahun 1980 telah dilakukan terapi CAPD secara insidentil (Tambunan, 2008) dan pada tahun 2004 tercatat 618 pasien mendapatkan pelayanan terapi CAPD (Situmorang, 2008). Sampai saat ini permasalahan komplikasi pada terapi CAPD masih ditemukan diantaranya mekanik, medikal dan infeksi (DeVore, 2008). Komplikasi infeksi yang sering adalah peritonitis mencapai $60-80 \%$ (Smeltzer \& Bare, 2008), tunnel infections, exit site (MacDougall, 2007). Studi pendahuluan yang dulakukan peneliti di Rumah Sakit Umum Dr Saiful Anwar Malang Jawa Timur, data pelayanan terapi CAPD dilakukan sejak tahun 2003 hingga bulan September 2008 jumlah pasien 173 orang, dari jumlah tersebut 82 pasien telah meninggal dunia, 10 pasien pindah terapi HD dan 2 pasien melakukan transplantasi ginjal, hingga 6 bulan terakhir ini yang mendapatkan pelayanan CAPD sebanyak 81 pasien. Dari 81 pasien CAPD di rumah sakit tersebut sebanyak 22 pasien CAPD diketahui pernah menderita komplikasi peritonitis.

Peritonitis adalah inflamasi peritoneum lapisan membran serosa rongga abdomen dan meliputi visera (Smeltzer \& Bare, 2008), peritonitis ini terjadi juga dihubungkan dengan proses bedah abdominal dan dialisis peritoneal (Sudoyo, 2006). Peritonitis disebabkan oleh kebocoran isi dari organ abdomen ke dalam rongga abdomen akibat dari infeksi, iskemik, trauma atau perforasi. Peritonitis pada CAPD lebih sering berasal dari kontaminasi mikro organisme pada kulit saat penggantian cairan dialisat, kontaminasi saat penggantian kateter, kolonisasi bakteri pada exit site dan tunnel infections. Proliferasi bakteri akan mengakibatkan terjadinya edema jaringan peritoneal, dalam waktu singkat terjadi eksudasi cairan. Cairan dalam rongga peritoneal menjadi keruh dengan meningkatnya jumlah protein, sel darah putih, debris seluler dan darah. Reaksi dari kondisi tersebut meningkatkan motilitas usus yang diikuti illeus paralitik sehingga terjadi akumulasi udara dan cairan dalam usus.

Penanganan tindakan dialisis merupakan suatu proses yang digunakan untuk mengeluarkan cairan dan produk limbah dari dalam tubuh ketika ginjal tidak mampu melaksanakan proses tersebut (Smeltzer \& Bare, 2008). Pada saat dialisis molekul solut berdifusi lewat membran semipermeabel dengan cara mengalir dari sisi cairan yang lebih pekat (konsentrasi solut lebih tinggi) ke cairan yang lebih encer (konsentrasi solut lebih rendah) (Gutch, Stoner \& Corea, 1999). Ada tiga cara terapi pengganti ginjal atau renal replacement therapy (RRT) salah satu diantaranya adalah CAPD (Sidabutar, 2006).

\section{METODE}

Jenis penelitian yang digunakan adalah deskriptif dengan rancangan cross sectional. Penentuan jumlah besaran sample dalam penelitian ini dengan menggunakan tehnik total sampling, yaitu keseluruhan sampel yang telah teridentifikasi sebanyak 22 responden pasien CAPD dengan komplikasi peritonitis dan 13 perawat yang bekerja diruang dialisis. Dengan karakteristik responden meliputi: pasien dengan terapi CAPD, pernah atau sedang mengalami peritonitis, kesadaran pasien composmentis, pasien yang telah menjalani rawat jalan, dan bersedia menjadi responden. Karakteristik perawat meliputi: perawat, perawat tetap yang bekerja di ruang dialisis, tidak berstatus 
magang, tidak sedang dalam status cuti kerja, dan bersedia menjadi responden.

Penelitian dilakukan pada tanggal 30 Oktober 2008 sampai dengan 24 Nopember 2008 di unit rawat jalan ruang CAPD Rumah Sakit Umum Dr Saiful Anwar Malang.

Instrumen pengumpulan data dalam penelitian ini menggunakan kuesioner yang terdiri atas karakteristik demografi (umur, jenis kelamin, tingkat pendidikan, penghasilan), status nutrisi, personal hygiene, kemampuan dalam melakukan perawatan dan tindakan dialisis dirumah, sistem pendukung dari pihak keluarga (helper), fasilitas perawatan CAPD di rumah dan standar pelayanan keperawatan (standar struktur, standar proses). Uji analisa statistik yang digunakan dalam penelitian ini adalah univariat dari karakteristik demografi (umur, jenis kelamin, tingkat pendidikan, penghasilan), status nutrisi, personal hygiene, kemampuan dalam melakukan perawatan dan tindakan dialisis di rumah, sistem pendukung dari pihak keluarga (helper), fasilitas perawatan CAPD di rumah dan standar pelayanan keperawatan (standar struktur, standar proses). Analisis bivariat dengan uji statistik chi square dan $\mathrm{T}$ independen untuk mengetahui hubungan faktor-faktor dengan kejadian peritonitis pada pasien CAPD.

\section{HASIL DAN PEMBAHASAN}

\section{Hasil}

\section{Faktor Risiko}

Tabel 1. Distribusi status nutrisi, personal hygiene, kemampuan pasien, sistem pendukung dan fasilitas perawatan $(\mathrm{N}=22)$

\begin{tabular}{llcc}
\hline No & \multicolumn{1}{c}{ Variabel } & Frekuensi (f) & Prosentase (\%) \\
\hline & Status nutrisi: & & \\
1 & < IMT & 10 & 45,5 \\
2 & Z IMT & 12 & 54,5 \\
& Jumlah & 22 & 100 \\
& Personal hygiene: & 13 & 59,1 \\
1 & Kurang baik & 9 & 40,9 \\
2 & Baik & 22 & 100 \\
& Jumlah & 14 & 63,6 \\
& Kemampuan pasien: & 8 & 36,4 \\
1 & Kurang baik & 22 & 100 \\
2 & Baik & & \\
& Jumlah & 11 & 50 \\
& Sistem pendukung: & 11 & 50 \\
1 & Kurang baik & 22 & 100 \\
2 & Baik & & \\
& Jumlah & 11 & 50 \\
& Fasilitas perawatan: & 11 & 50 \\
1 & Kurang baik & 22 & 100 \\
2 & Baik & & \\
& Jumlah & & \\
\hline
\end{tabular}

Dari tabel 1 didapatkan distribusi berdasarkan status nutrisi di bawah IMT sebanyak $10(45,5 \%)$ dan di atas IMT sebanyak 12 orang $(54,5 \%)$. Berdasarkan personal hygiene didapatkan kurang baik sebanyak 13 orang $(59,1 \%)$ dan baik sebanyak 9 orang $(40,9 \%)$. Berdasarkan kemampuan pasien didapatkan kurang baik sebanyak 14 orang $(63,3 \%)$ dan baik sebanyak 8 orang $(36,4 \%)$. Berdasarkan sistem pendukung didapatkan kurang baik dan baik masing-masing sebanyak 11 orang $(50 \%)$. Berdasarkan fasilitas perawatan didapatkan kurang baik dan baik masingmasing sebanyak 11 orang (50\%). 
Tabel 2. Distribusi standar struktur dan proses $(\mathrm{N}=13)$

\begin{tabular}{llcc}
\hline No & \multicolumn{1}{c}{ Variabel } & Frekuensi (f) & Prosentase (\%) \\
\hline & Standar struktur: & & \\
$\mathbf{1}$ & Kurang baik & 6 & 46,2 \\
$\mathbf{2}$ & Baik & 7 & 53,8 \\
& Jumlah & 13 & 100 \\
& Standar proses: & 2 & \\
$\mathbf{1}$ & Kurang baik & 11 & 15,4 \\
$\mathbf{2}$ & Baik & 13 & 84,6 \\
& Jumlah & & 100 \\
\hline
\end{tabular}

Dari tabel 2 didapatkan distribusi analisis standar kualitas pelayanan keperawatan beradasarkan standar struktur yang kurang baik sebanyak 6 responden $(46,2 \%)$ dan yang baik sebanyak 7 responden $(53,8 \%)$. Sedangkan berdasarkan standar proses yang kurang baik sebanyak 2 responden $(15,4 \%)$ dan yang baik sebanyak 11 responden $(84,6 \%)$.

\section{Hubungan Faktor Risiko Dengan Kejadian Peritonitis Pada CAPD}

Tabel 3. Hubungan umur dengan kejadian peritonitis pada CAPD ( $\mathrm{N}=22)$

\begin{tabular}{ccccc}
\hline Variabel & Mean & Standard Deviation & $\mathrm{p}$ value & $\mathrm{N}$ \\
\hline Umur & 44,32 & 12,392 & 0,702 & 22 \\
\hline
\end{tabular}

Dari tabel 3 didapatkan hasil analisis antara umur dengan kejadian peritonitis pada pasien CAPD bahwa rata-rata umur responden yang mengalami kejadian peritonitis adalah umur 44,32 tahun (standard deviation $=12,392$ ). Hasil uji analisa statistik didapatkan nilai $\mathrm{p}=0,702$ yang kesimpulannya

Hubungan Jenis Kelamin, Tingkat Pendidikan, Penghasilan, Status Nutrisi, Personal Hygiene, Kemampuan Pasien, Sistem Pendukung, Fasilitas Perawatan Dengan Kejadian adalah tidak ada hubungan yang signifikan antara umur dengan kejadian peritonitis pada pasien CAPD.

Tabel 4. Hubungan jenis kelamin, tingkat pendidikan, penghasilan, status nutrisi, personal hygiene, kemampuan pasien, sistem pendukung, fasilitas perawatan dengan kejadian peritonitis pada $\mathrm{CAPD}(\mathrm{N}=22)$

\begin{tabular}{|c|c|c|c|c|c|c|c|}
\hline \multirow[t]{3}{*}{ No } & \multirow[t]{3}{*}{ Variabel } & \multicolumn{4}{|c|}{ Kejadian peritonitis } & \multirow{3}{*}{$\begin{array}{c}\text { OR } \\
95 \% \mathrm{CI}\end{array}$} & \multirow[t]{3}{*}{ p-value } \\
\hline & & \multicolumn{2}{|c|}{ Tinggi } & \multicolumn{2}{|c|}{ Rendah } & & \\
\hline & & $\mathbf{n}$ & $\%$ & $\mathbf{n}$ & $\%$ & & \\
\hline & Jenis kelamin: & & & & & & 0,669 \\
\hline 1 & Laki-laki & 5 & 41,7 & 7 & 58,3 & 0,476 & \\
\hline \multirow[t]{2}{*}{2} & Perempuan & 6 & 60 & 4 & 60 & $0,086-2,628$ & \\
\hline & Tingkat pendidikan: & & & & & & 0,771 \\
\hline 1 & $\mathrm{SD}$ & 4 & 66,7 & 2 & 33,3 & 4 & \\
\hline 2 & SLTP & 1 & 33,3 & 2 & 66,7 & 1,5 & \\
\hline 3 & SLTA & 4 & 57,7 & 3 & 42,9 & 4 & \\
\hline 4 & D III & 0 & 0 & 2 & 100 & 4 & \\
\hline \multirow[t]{2}{*}{5} & S1 & 2 & 50 & 2 & 50 & $0,264-2,628$ & \\
\hline & Penghasilan: & & & & & & 1,000 \\
\hline 1 & $<\mathrm{UMR}$ & 6 & 46,2 & 74 & 53,8 & 0,686 & \\
\hline 2 & $\geq \mathrm{UMR}$ & 5 & 55,6 & & 44,4 & $0,124-3,784$ & \\
\hline
\end{tabular}




\begin{tabular}{|c|c|c|c|c|c|c|c|}
\hline & Status nutrisi: & & & & & & 0,032 \\
\hline 1 & $<\mathrm{IMT}$ & 8 & 80 & 2 & 20 & 12 & \\
\hline \multirow[t]{2}{*}{2} & $\geq \mathrm{IMT}$ & 3 & 25 & 9 & 75 & $1,581-91,084$ & \\
\hline & Personal hygiene: & & & & & & 0,387 \\
\hline 1 & Kurang baik & 8 & 61,5 & 5 & 38,5 & 3,200 & \\
\hline \multirow[t]{2}{*}{2} & Baik & 3 & 33,3 & 6 & 66,7 & $0,540-18,980$ & \\
\hline & Kemampuan pasien: & & & & & & 0,024 \\
\hline 1 & Kurang baik & 10 & 71,4 & 4 & 28,6 & 17,500 & \\
\hline \multirow[t]{2}{*}{2} & Baik & 1 & 12,5 & 7 & 87,5 & $1,596-191,892$ & \\
\hline & Sistem pendukung: & & & & & & $\overline{1,000}$ \\
\hline 1 & Kurang baik & 5 & 54,5 & 6 & 45,5 & 0,694 & \\
\hline \multirow[t]{2}{*}{2} & Baik & 6 & 45,5 & 5 & 54,5 & $0,130-3,732$ & \\
\hline & Fasilitas perawatan: & & & & & & 0,088 \\
\hline 1 & Kurang baik & 8 & 72,7 & 3 & 27,3 & 7,111 & \\
\hline 2 & Baik & 3 & 27,3 & 8 & 72,7 & $1,089-46,441$ & \\
\hline
\end{tabular}

Dari tabel 4 didapatkan hubungan tingkat kejadian peritonitis dengan jenis kelamin sebagian besar terjadi pada perempuan dengan angka kejadian tinggi sebanyak 6 responden $(60 \%)$ dan angka kejadian rendah sebanyak 4 responden (60\%). Sedangkan jenis kelamin laki-laki dengan angka kejadian tinggi sebanyak 5 responden $(41,7 \%)$ dan angka kejadian rendah sebanyak 7 responden $(58,3 \%)$.

Hubungan tingkat kejadian peritonitis dengan tingkat pendidikan SD pada angka kejadian tinggi sebanyak 4 responden $(66,7 \%)$ dan angka kejadian rendah sebanyak 2 responden (33,3\%), tingkat pendidikan SLTP dengan angka kejadian tinggi sebanyak 1 responden $(33,3 \%)$ dan angka kejadian rendah sebanyak 2 responden $(66,7 \%)$, tingkat pendidikan SLTA dengan angka kejadian tinggi sebanyak 4 responden $(57,7 \%)$ dan angka kejadian rendah sebanyak 3 responden $(42,9 \%)$, tingkat pendidikan D3 dengan angka kejadian tinggi sebanyak 0 responden dan angka kejadian rendah sebanyak 2 responden (100\%), tingkat pendidikan S1 dengan angka kejadian tinggi dan rendah masing-masing sebanyak 2 responden $(50 \%)$.

Hubungan tingkat kejadian peritonitis dengan penghasilan di bawah UMR pada angka kejadian tinggi sebanyak 6 responden $(46,2 \%)$ dan angka kejadian rendah sebanyak 7 responden $(53,8 \%)$, penghasilan di atas
UMR dengan angka kejadian tinggi sebanyak 5 responden $(55,6 \%)$, dan angka kejadian rendah sebanyak 4 responden $(44,4 \%)$.

Hubungan tingkat kejadian peritonitis dengan status nutrisi di bawah IMT pada angka kejadian tinggi sebanyak 8 responden (80\%) dan angka kejadian rendah sebanyak 2 responden (20\%), status nutrisi di bawah IMT pada angka kejadian tinggi sebanyak 3 responden (25\%) dan angka kejadian rendah sebanyak 9 responden $(75 \%)$.

Hubungan tingkat kejadian peritonitis dengan personal hygiene yang kurang baik pada angka kejadian tinggi sebanyak 8 responden $(61,5 \%)$ dan angka kejadian rendah sebanyak 5 responden $(38,5 \%)$, personal hygiene yang baik pada angka kejadian tinggi sebanyak 3 responden $(33,3 \%)$ dan angka kejadian rendah sebanyak 6 responden $(66,7 \%)$.

Hubungan tingkat kejadian peritonitis dengan kemampuan pasien yang kurang baik pada angka kejadian tinggi sebanyak 10 responden $(71,4 \%)$ dan angka kejadian rendah sebanyak 4 responden $(28,6 \%)$, kemampuan pasien yang baik pada angka kejadian tinggi sebanyak 1 responden $(12,5 \%)$ dan angka kejadian rendah sebanyak 7 responden $(87,5 \%)$.

Hubungan tingkat kejadian peritonitis dengan sistem pendukung yang kurang baik pada angka kejadian tinggi sebanyak 5 responden $(54,5 \%)$ dan angka kejadian 
rendah sebanyak 6 responden $(45,5 \%)$, sistem pendukung yang baik pada angka kejadian tinggi sebanyak 6 responden $(45,5 \%)$ dan angka kejadian rendah sebanyak 5 responden $(54,5 \%)$.

Hubungan tingkat kejadian peritonitis dengan fasilitas perawatan yang kurang baik pada angka kejadian tinggi sebanyak 8 responden $(72,7 \%)$ dan angka kejadian rendah sebanyak 3 responden $(27,3 \%)$, fasilitas perawatan yang baik pada angka kejadian tinggi sebanyak 3 responden $(27,3 \%)$ dan angka kejadian rendah sebanyak 8 responden $(72,7 \%)$.

\section{Hubungan Standar Pelayanan Keperawatan Dengan Kejadian Peritonitis Pada CAPD}

Tabel 5. Hubungan standar pelayanan keperawatan dengan kejadian peritonitis pada CAPD $(\mathrm{N}=13)$

\begin{tabular}{|c|c|c|c|c|c|c|c|}
\hline \multirow[t]{3}{*}{ No } & \multirow[t]{3}{*}{ Variabel } & \multicolumn{4}{|c|}{ Kejadian Peritonitis } & \multirow{3}{*}{$\begin{array}{c}\text { OR } \\
95 \% \mathrm{CI}\end{array}$} & \multirow[t]{3}{*}{ p value } \\
\hline & & \multicolumn{2}{|c|}{ Tinggi } & \multicolumn{2}{|c|}{ Rendah } & & \\
\hline & & $\mathbf{n}$ & $\%$ & $\mathbf{n}$ & $\%$ & & \\
\hline & Standar struktur: & & & & & & \\
\hline & Kurang baik & & & & & & 0,203 \\
\hline 1 & Baik & 2 & 50 & 2 & 50 & 8,00 & \\
\hline \multirow[t]{3}{*}{2} & & 1 & 11,1 & 8 & 88,9 & $0,495-36,442$ & \\
\hline & Standar proses: & & & & & & \\
\hline & Kurang baik & & & & & & 0,559 \\
\hline 1 & Baik & 2 & 33,3 & 4 & 66,7 & 3,00 & \\
\hline 2 & & 1 & 14,3 & 6 & 85,7 & $0,119-45,244$ & \\
\hline
\end{tabular}

\section{Pembahasan}

Pada tabel 3 terdapat peningkatan umur seseorang yang semakin tua memberikan dampak pada menurunnya fungsi sistem dalam tubuh sehingga pertahanan tubuh terhadap suatu penyakit juga menurun. Peningkatan umur erat kaitannya dengan prognosa suatu penyakit dan harapan hidup, mereka yang berusia di atas 55 tahun kecenderungan untuk terjadi berbagai komplikasi yang memperberat fungsi ginjal lebih besar dibandingkan yang berusia di bawah 40 tahun (Fefendi, 2008). Peneliti belum menemukan penelitian yang terkait umur dengan kejadian peritonitis pada CAPD.

Pada tabel 4 mengenai analisis hubungan antara jenis kelamin dengan kejadian peritonitis pada pasien CAPD diperoleh hasil bahwa responden perempuan mempunyai kejadian peritonitis lebih tinggi dibanding dengan responden laki-laki, artinya perempuan berpotensi mengalami kejadian peritonitis lebih tinggi dibandingkan dengan laki-laki. Hasil uji statistik diperoleh nilai $\mathrm{p}=$
0,669 maka disimpulkan tidak ada hubungan yang signifikan antara jenis kelamin laki-laki dan perempuan dengan kejadian peritonitis pada pasien CAPD. Hasil penelitian yang dilakukan oleh Gan., et al. (2003) didapatkan bahwa dari 34 responden 20 diantaranya adalah jenis kelamin laki-laki, namun belum menjelaskan alasan mengapa laki-laki lebih banyak. Kecenderungan laki-laki kurang perhatian terhadap perawatan diri dibanding perempuan, sedangkan perempuan lebih banyak memperhatikan diri secara total termasuk dalam perawatan dialisis yang harus dilakukan pada dirinya setiap hari.

Analisis hubungan antara tingkat pendidikan dengan kejadian peritonitis pada pasien CAPD diperoleh hasil bahwa pendidikan SD dan SLTA berpotensi mengalami kejadian peritonitis tinggi dibandingkan dengan pendidikan SLTP, D3 dan S1. Pendidikan SLTP, D3 dan S1 mempunyai peluang 4 kali mengalami kejadian peritonitis tinggi dibandingkan dengan SD dan SLTA. Hasil uji statistik diperoleh nilai $\mathrm{p}=0,771$ maka disimpulkan tidak ada hubungan yang signifikan antara tingkat 
pendidikan dengan kejadian peritonitis pada pasien CAPD. Tingkat pendidikan pasien CAPD ada hubungan dengan kemungkinan terjadinya komplikasi, karena kemampuan penyerapan pengetahuan pasien saat mendapatkan edukasi dalam bentuk pelatihan dipengaruhi tingkat pendidikan yang dimiliki. Tingkat pendidikan turut berkontribusi dalam penyerapan keberhasilan pelatihan yang diberikan pada pasien termasuk kemampuan baca tulis (Tambunan, 2008).

Analisis hubungan antara penghasilan (UMR) dengan kejadian peritonitis pada pasien CAPD adalah $(55,6 \%)$ penghasilan e" UMR mempunyai kejadian peritonitis lebih tinggi dibanding dengan responden yang memiliki penghasilan < UMR. Hasil uji statistik diperoleh nilai $\mathrm{p}=1,000$ maka disimpulkan tidak ada hubungan yang signifikan antara penghasilan (UMR) dengan kejadian peritonitis pada pasien CAPD. Kemampuan pasien dalam memanfaatkan fasilitas kesehatan tergantung dari kemampuan ekonomi yang dimiliki, penghasilan yang rendah berdampak pada kemampuan untuk pengobatan terlebih jika harus dilakukan secara terus menerus. Beberapa penyakit kronis (gagal ginjal kronik) memerlukan biaya yang besar untuk biaya perawatan dan pengobatan apabila harus dilakukan dialisis atau transplantasi ginjal (Fefendi, 2008).

Analisis hubungan antara status nutrisi (IMT) dengan kejadian peritonitis pada pasien CAPD adalah $(80 \%)$ dengan status nutrisi < IMT mempunyai kejadian peritonitis lebih tinggi dibanding dengan status nutrisi e" IMT, artinya status nutrisi < IMT berpotensi mengalami kejadian peritonitis tinggi dibandingkan dengan status nutrisi e" IMT. Status nutrisi < IMT mempunyai peluang 12 kali mengalami kejadian peritinitis tinggi dibandingkan dengan status nutrisi e" IMT. Hasil uji statistik diperoleh nilai $\mathrm{p}=0,032 \mathrm{maka}$ disimpulkan ada hubungan yang signifikan antara status nutrisi (IMT) dengan kejadian peritonitis pada pasien CAPD. Peritonitis berdampak pada kehilangan protein melalui peritonium dalam jumlah besar sehingga mengakibatkan malunitrisi (Smeltzer \& Bare, 2008), pengeluaran protein berlebihan dimungkinkan saat pengeluaran cairan dialisat dan penurunan nilai normal IMT (Hudak \& Gallo,1996). Status nutrisi yang rendah pada pasien CAPD akibat pengeluaran protein yang berlebihan, berisiko terhadap penurunan daya tahan tubuh dan memungkinkan rendahnya daya tangkal pada mikro organisme yang menyerang tubuh.

Analisis hubungan antara personal hygiene dengan kejadian peritonitis pada pasien CAPD didapatkan $(61,5 \%)$ dengan personal hygiene kurang baik mempunyai kejadian peritonitis lebih tinggi dibanding dengan responden personal hygiene baik, artinya personal hygene kurang baik berpotensi mengalami kejadian peritonitis tinggi dibandingkan dengan personal hygiene baik. Personal hygiene kurang baik mempunyai peluang 3,2 kali mengalami kejadian peritonitis tinggi dibandingkan dengan personal hygiene baik. Hasil uji statistik diperoleh nilai $\mathrm{p}=0,387$ maka disimpulkan tidak ada hubungan yang signifikan antara personal hygiene dengan kejadian peritonitis pada pasien CAPD. Untuk mencegah berkembangnya mikro organisme patogen pada pasien CAPD harus diperhatikan kebersihan diri (Tambunan,2008). Upaya untuk mempertahankan personal hygene dengan melakukan kebersihan diri tiap hari secara rutin seperti: mandi, gosok gigi, ganti baju, potong kuku dan membersihkan sekitar exit site dengan kasa steril setiap selesai mandi.

Analisis hubungan antara kemampuan perawatan dialisis di rumah dengan kejadian peritonitis pada pasien CAPD didapatkan $(71,4 \%)$ dengan kemampuan perawatan dialisis di rumah kurang baik mempunyai kejadian peritonitis lebih tinggi dibanding dengan kemampuan perawatan dialisis baik, artinya kemampuan perawatan dialisis kurang baik berpotensi mengalami kejadian 
peritonitis tinggi dibandingkan dengan kemampuan perawatan dialisis baik. Kemampuan perawatan dialisis kurang baik mempunyai peluang 17,5 kali mengalami kejadian peritonitis tinggi dibandingkan dengan kemampuan perawatan dialisis baik. Hasil uji statistik diperoleh nilai $\mathrm{p}=0,024$ maka disimpulkan ada hubungan yang signifikan antara kemampuan perawatan dialisis di rumah dengan kejadian peritonitis pada pasien CAPD. Kemampuan perawatan di rumah ini menyangkut tentang tehnik melakukan dialisis secara benar, kemampuan mengenal adanya komplikasi dan kecepatan menghubungi perawat atau dokter jika terjadi masalah (Tambunan, 2008). Kemampuan perawatan dialisis di rumah kurang baik berdampak pada tidak adekuatnya perawatan yang harus dilakukan sesuai standar, masalah ini memicu cepatnya pertumbuhan mikro organisme dan memudahkan terjadinya komplikasi.

Analisis hubungan antara sistem pendukung dengan kejadian peritonitis pada pasien CAPD didapatkan $(54,5 \%)$ sistem pendukung baik mengalami kejadian peritonitis tinggi dibanding dengan sistem pendukung kurang baik. Hasil uji statistik diperoleh nilai $\mathrm{p}=1,000$ maka disimpulkan tidak ada hubungan yang signifikan antara sistem pendukung dengan kejadian peritonitis pada pasien CAPD. Sistem pendukung yang berasal dari keluarga atau penolong lainya (helper) yang adequat akan meningkatkan motivasi pasien untuk tetap konsisten dalam perawatan CAPD. Keluarga diharapkan turut dalam pengelolaan perawatan dan pengobatan pasien CAPD (Tambunan, 2008).

Analisis hubungan antara fasilitas perawatan CAPD di rumah dengan kejadian peritonitis pada pasien CAPD didapatkan $(72,7 \%)$ dengan fasilitas perawatan CAPD di rumah kurang baik mempunyai kejadian peritonitis lebih tinggi dibanding dengan responden yang memiliki fasilitas perawatan baik, artinya fasilitas perawatan kurang baik berpotensi mengalami kejadian peritonitis tinggi dibandingkan dengan fasilitas perawatan baik. Fasilitas perawatan kurang baik mempunyai peluang 7,1 kali mengalami kejadian peritonitis tinggi dibandingkan dengan fasilitas perawatan baik. Hasil uji statistik diperoleh nilai $\mathrm{p}=0,088$ maka disimpulkan tidak ada hubungan yang signifikan antara fasilitas perawatan CAPD di rumah dengan kejadian peritonitis pada pasien CAPD. Tidak tersedianya fasilitas perawatan yang memadai memberikan kontribusi terjadinya peritonitis. Adapun fasilitas perawatan yang diharapkan adalah tersedianya kamar khusus untuk mengganti cairan dialisat dan adanya air mengalir untuk cuci tangan (Tambunan, 2008).

Pada tabel 5 hasil analisis hubungan antara standar pelayanan keperawatan dengan kejadian peritonitis pada pasien CAPD pada standar struktur diketahui bahwa 50\% dengan standar struktur kurang baik mempunyai kejadian peritonitis lebih tinggi dibanding dengan responden yang memiliki standar struktur baik, artinya standar struktur kurang baik berpotensi menunjang kejadian peritonitis tinggi dibandingkan dengan standar struktur baik. Standar struktur kurang baik mempunyai peluang 8 kali menunjang kejadian peritinitis tinggi dibandingkan dengan standar struktur baik. Hasil uji statistik diperoleh nilai $\mathrm{p}=0,203$ maka disimpulkan tidak ada hubungan yang signifikan antara standar kualilitas pelayanan keperawatan (standar struktur) dengan kejadian peritonitis pada pasien CAPD. Standar kualitas pelayanan keperawatan (standar struktur) merupakan standar yang berfokus pada karaktristik internal dalam organisasi dan karakteristik perawat. Standar proses berfokus pada tahapan kegiatan pada pasien CAPD mulai dari asuhan predialisis, rawat inap, sebelum dan selama pelatihan, perawatan dialisis dirumah (Yetti, 2007).

\section{KESIMPULAN DAN SARAN}

Implikasi dari penelitian ini bahwa terapi CAPD merupakan tindakan dialisis yang 
memerlukan insisi pada peritonium untuk pemasangan kateter, sehingga rentan akan terjadinya komplikasi satu di antaranya adalah peritonitis. Peran perawat adalah menjamin kualitas pelayanan keperawatan secara prima sehingga kejadian komplikasi pada pasien CAPD dapat diminimalkan. Hasil penelitian ini dapat digunakan sebagai sumber informasi untuk perawat khususnya yang menekuni tentang perawatan CAPD. Untuk kekhususan keperawatan medikal bedah, hasil penelitian ini dapat digunakan sebagai dasar pengkajian lebih luas dan lebih spesifik dalam membuat analisis dan sintesa yang berhubungan dengan kasus CAPD.

Hasil penelitian disimpulakan bahwa responden yang mengalami kejadian peritonitis rata-rata berusia 44,32 tahun dengan jenis kelamin terbanyak adalah lakilaki, tingkat pendidikan terbanyak adalah SLTA dan sebagian besar mempunyai penghasilan kurang dari UMR. Dari status nutrisi diketahui hampir sebagian besar responden dengan status nutrisi lebih dari sama dengan IMT dan personal hygiene sebagian besar kurang baik. Kemampuan pasien dalam perawatan dialisis di rumah sebagian besar kurang baik sedangkan dalam hal sistem pendukung dan fasilitas perawatan CAPD di rumah sebagian kurang baik. Standar kualitas pelayanan keperawatan pada standar struktur dan standar proses sebagian besar adalah baik. Umur, jenis kelamin, tingkat pendidikan dan penghasilan tidak ada hubungan dengan kejadian peritonitis pada pasien CAPD. Status nutrisi, kemampuan perawatan dialisis ada hubungan dengan kejadian peritonitis pada pasien CAPD, sedangkan personal hygiene, sistem pendukung, fasilitas perawatan CAPD di rumah, standar struktur dan standar proses tidak ada hubungan dengan kejadian peritonitis pada pasien CAPD.

\section{DAFTAR PUSTAKA}

Anonymous. 2008. Essential Qualities of a Renal Nurse. Makalah Studi Ilmiah.
Disampaikan pada Ulang Tahun RS PGI

Cikini ke 110. Dipublikasikan tanggal 16 \& 17 Pebruari 2008.

Anonymous. 2007. Renal Replacement Therapy. http://www.kalbe.co.id/ i n d e x p p p ? m n = p r o d u c t \&tipe $=3 \&$ cat $=311$. Diperoleh tanggal 10 September 2008.

Anonymous. 2008. Trainning CAPD. PPSDM Rumah Sakit PGI Cikini. Jakarta: Makalah Kursus Perawatan Intensif Ginjal XIV. Dipublikasikan.

DeVore, V.S. 2008. Continuose Ambulatory Peritoneal Dialysis (CAPD) and Its Camplications. http://www.renal.org/ guedelines/ module3b.html. Diperoleh tanggal 17 September 2008.

Gan., at al. 2003. A Study on Early Onset Peritonitis in CAPD Patiens. Singapore Med. http://www. sma.org.sg/smj/4403/ 4403a5.pdf. Diperoleh tanggal 2 September 2008.

Gutch, C.F., Stoner, M.H., Corea, \& Anna L. 1999. Review of Hemodialysis for Nurses and Dialysis Personnel. $6^{\text {th }}$ Edition. St Louis. Missouri: Mosby, Inc. Hudak \& Gallo. 1997. Critical Care Nursing: A Holistic Approach. Philadelphia: Lippincott Company J.B.

MacDougall, D. 2007. CAPD Peritonitis: Causes, Management, Renal \& Urology News. http:// www.renalandurologynews.com/ CAPDPeritonitisCausesManagement/ article/99060/. Diperoleh tanggal 12 September 2008.

Situmorang, T. 2008. Pengyakit Ginjal Akut \& Kronik Penyakit Diabetik \& Metabolik (DM\&Lupus) Integrasi Terapi Pengganti Ginjal Resep dan Adequasi pada Hemodialisis. PPSDM Rumah Sakit PGI Cikini. Jakarta: Makalah Kursus Perawatan Intensif Ginjal XIV. Dipublikasikan.

Sidabutar, H. 2008. Anatomi dan Fisiologi Ginjal. PPSDM Rumah Sakit PGI Cikini. Jakarta: Makalah Kursus Perawatan Intensif Ginjal XIV. Dipublikasikan. 
Sidabutar, R.P. 2005. Penanggulangan Gagal Ginjal Kronik dan Kemajuannya. Sub Bagian Ginjal Hipertensi Bagian Ilmu Penyakit Dalam FK UI RSCM. Jakarta: http://www.sjkdt.org/article.asp Diperoleh tanggal 17 September 2008.

Smeltzer \& Bare. 2008. Brunner and Suddarth's Textbook of MedicalSurgical Nursing. $10^{\text {th }}$ Edition. Philadelphia: Lippincott Williams \& Wilkins.

Tambunan R. 2008. Asuhan Keperawatan pada Pasien Dialisis. PPSDM Rumah Sakit PGI Cikini. Jakarta: Makalah Kursus Perawatan Intensif Ginjal XIV. Dipublikasikan.

Yetti, K. 2007. Peran Perawat Dalam Meningkatkan Kualitas Pasien Peritoneal Dialisis. Jurnal Keperawatan Indonesia. Volume 11. Jakarta: Universitas Indonesia. 